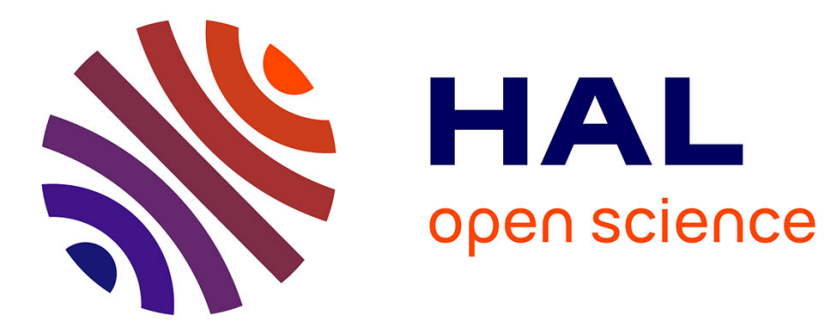

\title{
A geometric approach for PV modules degradation
}

Bechara Nehme, Nkm 'Sirdi, Tilda Akiki

\section{To cite this version:}

Bechara Nehme, Nkm 'Sirdi, Tilda Akiki. A geometric approach for PV modules degradation. REDEC-2014, Nov 2014, Beirut, Lebanon. hal-01078630

\section{HAL Id: hal-01078630 \\ https://hal-confremo.archives-ouvertes.fr/hal-01078630}

Submitted on 29 Oct 2014

HAL is a multi-disciplinary open access archive for the deposit and dissemination of scientific research documents, whether they are published or not. The documents may come from teaching and research institutions in France or abroad, or from public or private research centers.
L'archive ouverte pluridisciplinaire HAL, est destinée au dépôt et à la diffusion de documents scientifiques de niveau recherche, publiés ou non, émanant des établissements d'enseignement et de recherche français ou étrangers, des laboratoires publics ou privés. 


\title{
A geometric approach for PV modules degradation
}

\author{
Bechara Nehme ${ }^{1,2}$, Nacer K. M'Sirdi ${ }^{1}$, Tilda Akiki ${ }^{2}$ \\ ${ }^{1}$ Aix Marseille Université, CNRS, ENSAM \\ Université de Toulon, LSIS UMR 7296 \\ 13397, Marseille France \\ ${ }^{2}$ Département de Génie Électrique et Électronique \\ Faculté d'Ingénierie, Université Saint-Esprit de Kaslik \\ B.P. 446 Jounieh, Mont Liban - Liban \\ becharanehme@usek.edu.lb
}

\begin{abstract}
This paper presents an overview of two degradation modes of PV panels: the Moisture Induced Degradation and the Cell Cracks. The two mentioned degradation modes affect PV cells differently according to their position in the module. At a previous stage, we have build a PV model that takes into consideration three degradation modes, the Potential Induced Degradation, the Light Induced Degradation, and the Ultraviolet Light Degradation. In this paper, we update our model to take into consideration all degradation modes.
\end{abstract}

Index Terms-Moisture Induced Degradation, Cracks Degradation, Geometric position, Efficiency, Modeling.

\section{INTRODUCTION}

With the growth of PV (Photovoltaic) part in energy production, reliability and degradation are two concerns of main importance that must be studied for module life span. In fact, investors in power production are expecting the minimum price per $\mathrm{kWh}$ produced. From here derives our objective to increase the life span of PV panels.

Other arguments defend our objective. In fact, PV panels need at least three years to generate the power needed for their fabrication. Second, the fabrication of PV panels needs rare raw materials like Indium, Silver, Germanium, and Gallium. Third, some PV panels contain carcinogenic elements like Cadmium and Lead [1].

Many PV specialists are studying the degradation of PV panels [2-8]. They use accelerated tests to show the effect of environmental conditions on PV panels. Melissa A. Yaklin and al. showed the effect of humidity on TCO (Transparent Conductive Oxide) [2]. Michael D. Kempe focused on the ingress of moisture into PV panels [3]. Jane Kapur and al. showed the geometrical repartition of moisture in the PV panel [4]. On the other hand, Sarah Kajari-Schröder and al. showed the geometrical and directional repartition of cracks in a PV panel [5]. S. Kajari-Schröder and al. explained when cracks become critical to PV cell [6]. M. Köntges and al. simulated the effect of cracks on power production [7].

In previous works, we developed a PV model that simulates the efficiency as a function of time. Our model takes into consideration the PID (Potential Induced Degradation), the LID (Light Induced degradation), and the UVD (Ultraviolet Light Degradation) [8]. Our panel is made of two strings of 12 cells each. Each cell delivers 5.5A under the STC (Standard Test Conditions).
In this paper, we represent first the equivalent circuit of a PV cell. Then we overview the MID (Moisture Induced Degradation), and we model the effect of moisture on the equivalent circuit of PV cells. The modeling takes into consideration the position of cells in the panel. Then we overview the cell cracks. And we model their effect on the equivalent circuit of PV cells. At the end, we upgrade our existing model to consider all degradation modes. We use our model to evaluate the efficiency of PV panels as a function of time and environmental conditions.

Mismatch losses that arise from un-uniform degradation are underlined in this article.

\section{EQUIVALENT CIRCUIT OF A PV CELL}

A PV cell can be modeled like a current source; its electrical model is compose

$\mathrm{d}$ of a current source $\left(\mathrm{I}_{\mathrm{SC}}\right)$ mounted in parallel with two diodes (D1 and D2) and a shunt resistor $\left(\mathrm{R}_{\mathrm{sh}}\right)$. A series resistor $\left(\mathrm{R}_{\mathrm{s}}\right)$ is added to complete the model. The current generated $\mathrm{I}_{\mathrm{SC}}$ is proportional to the incident irradiance $\mathrm{G}$ in W. $\mathrm{m}^{-2}$ and to the temperature $\mathrm{T}$ in $\mathrm{K}$. The current flowing in the shunt resistor $\left(\mathrm{R}_{\mathrm{sh}}\right)$ represents the leakage current in the edge of the cell. The resistor $R_{S}$ represents the internal losses of the PV cell caused by the electric contact. The current I (in A) flowing in the load will become [1]:

$$
I=I_{S C}-I_{01}\left(\exp \left(\frac{e\left(V+I R_{s}\right)}{K T}\right)-1\right)-I_{02}\left(\exp \left(\frac{e\left(V+I R_{s}\right)}{2 K T}\right)-1\right) \frac{\left(\mathrm{V}+\mathbb{R}_{s}\right)}{R_{h h}}
$$

Where, $\mathrm{I}_{01}$ : is the saturation current of diode D1 in A. $\mathrm{I}_{02}$ : is the saturation current of the diode D2 in A. $\mathrm{e}:$ is the electron charge $\left(1.6 \times 10^{-19} \mathrm{C}\right)$. $\mathrm{V}$ : is the output voltage of the cell in $\mathrm{V}$. $\mathrm{K}$ : is the Boltzmann constant $1.3806 \times 10^{-23} \mathrm{~J}^{-\mathrm{K}^{-1}}$. $\mathrm{T}$ : is the temperature in $\mathrm{K}$. 


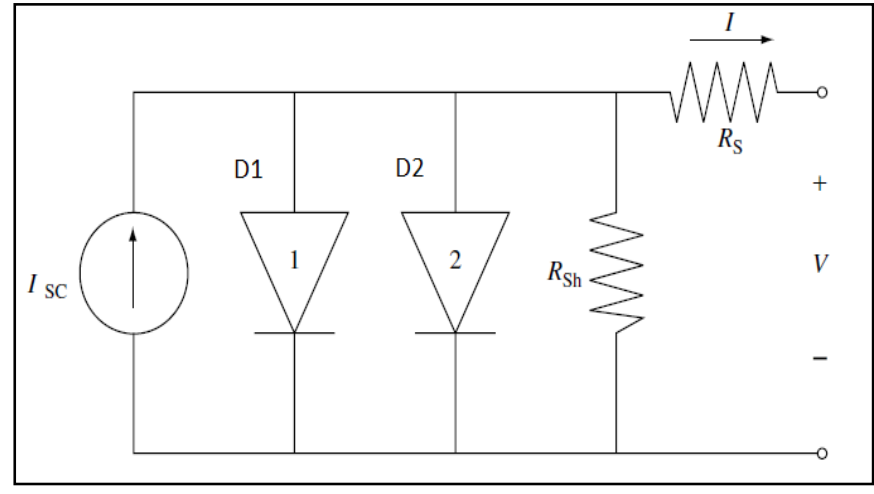

Figure 1. Equivalent circuit of a PV cell.

\section{GEOMETRY OF A PV PANEL}

The current and the voltage delivered by one solar cell are small for being useful. This implies the need of connecting cells in series and in parallel to form a module capable of delivering useful voltage and current. In this paper, we consider a panel composed of two strings of 12 cells each. We adopt the configuration shown in Fig 2.

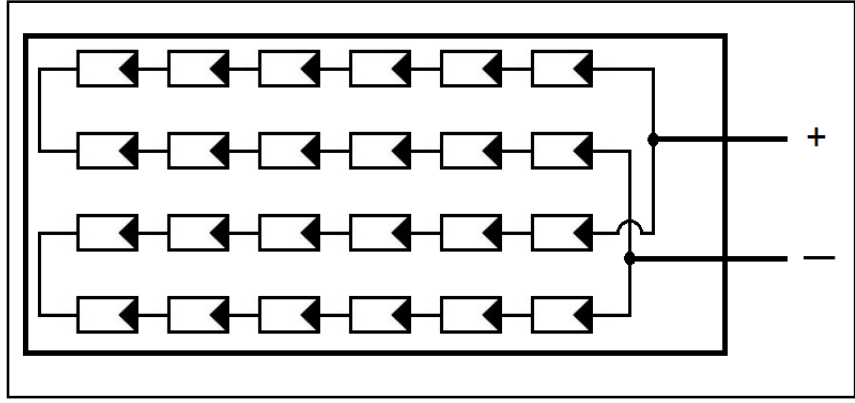

Figure 2. Desired configuration of the panel model.

\section{MID: MOISTURE INDUCED DEGRADATION}

\section{A. MID overview}

PV panels are subject to moisture degradation. This is why they undergo a Damp Heat test (DH). In the DH test, the panels or cells are exposed to an environment specified by an 85\% RH (Relative Humidity) and an $85{ }^{\circ} \mathrm{C}$. The test lasts for $1000 \mathrm{~h}$. According to IEC61646 standard, the efficiency of the panels must not decrease more than 5\% [9]. Humidity degrades PV panels by causing delamination and mainly increasing the series resistance of the equivalent circuit. In fact, it degrades the TCO layer.

\section{B. MID Modeling}

The TCO layer is used in thin film technologies because of its conductivity, transparency, and low cost. The TCO degrades under effect of humidity; its resistance increases. To investigate the effect of humidity on the resistance of the TCO, many experiments in literature were elaborated [2-3-4,9]. Results of these experiments done by Melissa A. Yaklin and al. show that degradation follows an Arrhenius equation with an activation energy of $0.91 \mathrm{eV}$ [2]. Besides, temperatures lower than $44^{\circ} \mathrm{C}$ did not show any degradation. In addition, TCO degradation is proportional to the relative humidity. Analyzing the literature experiences and using an empiric method we can derive the resistance of the TCO layer as a function of time by:

$$
R_{s}=R_{0}+4 \times 10^{10} \times \exp \left(\frac{-87500}{R \times T}\right) \times R H \times t
$$

Where, $\mathrm{R}_{0}$ : initial TCO layer resistance in $\Omega$.

$\mathrm{R}$ : Gas constant $8.314 \mathrm{~J} \cdot \mathrm{mol}^{-1} \cdot \mathrm{K}^{-1}$.

$\mathrm{T}$ : temperature in $\mathrm{K}$.

RH: relative humidity.

t: time in hours.

It is clear that high degradation occurs when high temperature and high relative humidity combines [2].

As humidity affects TCO layer of PV panels, we must study the ingress of humidity into the panel. We define the WVTR (Water Vapor Transmission Rate) which indicates the passage of water trough the encapsulant layer. The WVTR in $\mathrm{g} . \mathrm{cm}^{-2} \cdot \mathrm{s}^{-1}$ is given by the following formula [4]:

$$
W V T R=\frac{P}{l}\left[1+2 \sum_{n=1}^{\infty}(-1)^{n} \exp \left(\frac{-D n^{2} \pi^{2} t}{l}\right)\right]
$$

Where, $\mathrm{P}$ : permeability in $\mathrm{cm}^{2}$.

1: encapsulant thickness in $\mathrm{cm}$.

D: diffusion coefficient in $\mathrm{cm}^{2} \cdot \mathrm{s}^{-1}$.

$\mathrm{t}$ : time in $\mathrm{s}$.

At steady state, the WVTR is equal to $\frac{P}{l}$. We must note that the WVTR follows an Arrhenius equation with an activation energy of $0.38 \mathrm{eV}$. We must also note that moisture is susceptible to ingress through the edges of the panel. Mathematically, with some approximation, moisture repartition follows a sine function having the lower value at the center of the panel and the higher value near the edges [4].

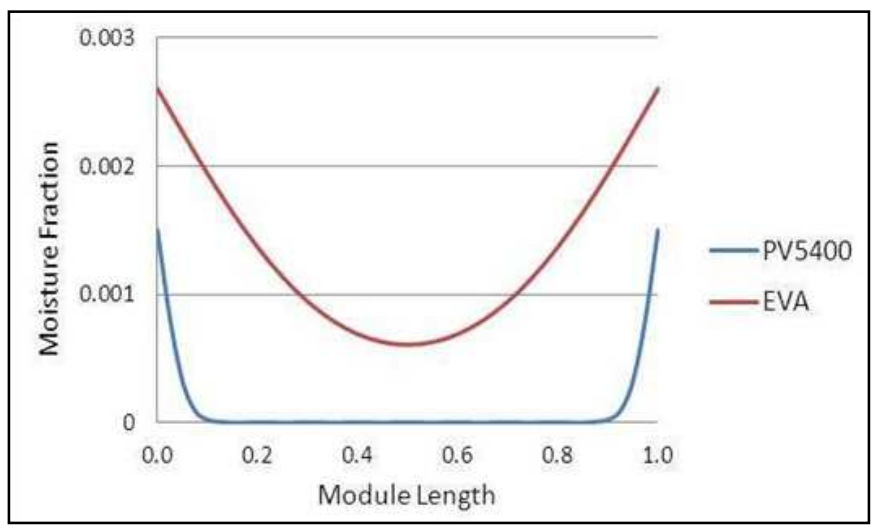

Figure 320 years from [4]

The RH in equation 2 can be substituted by the actual level of moisture fraction from Fig 3. We consider PV modules 
having an EVA (Ethylene Vinyl Acetate) encapsulation and a TCO layer. The series resistance of each cell is given by:

$$
R_{s}=0.1+4 \times 10^{10} \exp \left(\frac{-87500}{R \times T}\right) \sin (\text { Dist }) \exp \left(\frac{-36678}{R \times T_{a v}}\right) R H_{e x t} t \text { (4) }
$$

Where, Dist: Distance from centre (Table 1).

$\mathrm{RH}_{\text {ext }}$ : external Relative Humidity.

$\mathrm{T}$ : temperature of the Panel in $\mathrm{K}$.

$\mathrm{T}_{\mathrm{av}}$ : average temperature in $\mathrm{K}$.

$\mathrm{t}$ : time in hours.

Table 1. Normalized distance from centre.

\begin{tabular}{|c|c|c|c|c|c|}
\hline 1 & 0.75 & 0.75 & 0.75 & 0.75 & 1 \\
\hline 0.75 & 0.5 & 0.25 & 0.25 & 0.5 & 0.75 \\
\hline 0.75 & 0.5 & 0.25 & 0.25 & 0.5 & 0.75 \\
\hline 1 & 0.75 & 0.75 & 0.75 & 0.75 & 1 \\
\hline
\end{tabular}

We consider that the ingress of moisture is a relative low phenomenon; the temperature used to calculate the ingress is the average temperature. The degradation happens at the actual temperature of the panel.

\section{CELl CRACKS}

\section{A. Cells Cracks overview}

PV panels are laminates generally formed by pilling a glass superstrate, EVA encapsulation, cells, another EVA encapsulation, and the backsheet. The panel is then sealed with an aluminum frame. During manufacturing process and when exposed to mechanical loads (transportation, wind, snow...), cells suffer from cracks formation due to their plastic properties.

We focus on crack formation in crystalline silicon based PV cells. The cells are connected using a silver printed grid on the surface of the cell. A copper bus-bar is soldered perpendicularly to the silver grid to connect adjacent cells.

After formation a crack may not be harmful to a PV cell. We talk about cracks criticality. In fact, cracks divide the cell area into regions. A region becomes inactive if it is no more connected to the bus-bar. From the latter, if a crack is perpendicular to the bus-bars, it will not affect the cell. If a crack is parallel to the bus-bars and is situated between the two bus-bars, it will not affect the cell. If a crack is parallel to the bus-bars and is situated in the external area, it will isolate an area of the cell making it inactive Fig 5 [5]. Dendritic cracks may also lead to some isolated areas of the cell.

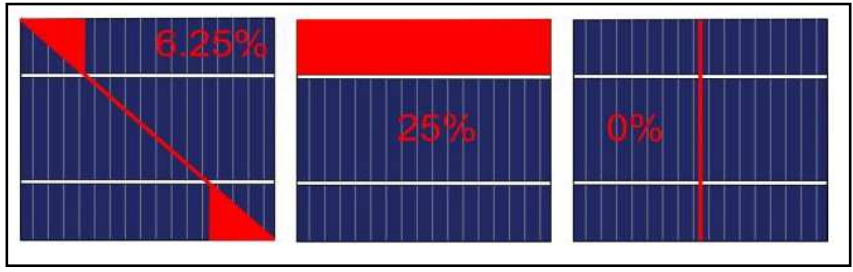

Figure 4. Cracks orientation from [5].

A PV panel is mechanically modeled as a Navier plate; the frame is defined to have infinite stiffness and the laminate is considered to have the bending of a glass [5]. One of the most important environment effects on cell cracks is the snow. The latter is modeled by a uniform load on the Navier plate. Simulations and examinations of panels done by Schröder and al. give the following repartition and direction of cracks:

- Cracks are likely to happen on the diagonals and more on the center

- Cracks formation is negligible near the middle of edges

- Cracks orientation is parallel to diagonals in the diagonals

- Cracks orientation is parallel to the long edges in the centre

It is clear that the most deteriorated cells are those located at the center and at the diagonals. In the center, strain is parallel to the small edges of the panel forming cracks parallel to the large edges of the panel or parallel to the bus-bars. In the diagonals, strain is perpendicular to the diagonals forming cracks parallel to the diagonals or making an angel with busbars [5].

Although orientation is important, it does not affect cells operation until it becomes deep and isolates cell areas. Based on experimental results, many cycles of humidity-freeze are needed to deepen the cracks and decrease the power output of the panel [6].

\section{B. Cells Cracks Modeling}

Cracks are generally a recombination center for electronhole pairs. However, when cell regions are isolated or inactive, the photo-generated current $\mathrm{I}_{\mathrm{SC} \text { cracked }}$ and the recombination current $\left(\mathrm{I}_{01 \text { cracked }}\right.$ and $\left.\mathrm{I}_{02 \text { cracked }}\right)$ will decrease respecting the following equations $[7,10]$ :

$$
\begin{aligned}
& I_{\text {SCracked }}=I_{S C}\left(1-\frac{A_{\text {inactive }}}{A_{\text {total }}}\right) \\
& I_{01 \text { cracked }}=I_{01}\left(1-\frac{A_{\text {inactive }}}{A_{\text {total }}}\right)
\end{aligned}
$$




$$
I_{02 \text { cracked }}=I_{02}\left(1-\frac{A_{\text {inactive }}}{A_{\text {total }}}\right)
$$

Where, $\mathrm{I}_{\text {SCcracked: }}$ the short circuit current after crack formation in A.

$\mathrm{A}_{\text {inactive: }}$ isolated area of the cell in $\mathrm{m}^{2}$.

$\mathrm{A}_{\text {total }}$ : total area of the cell in $\mathrm{m}^{2}$.

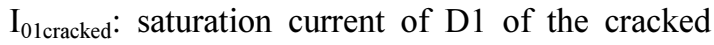
cell in A.

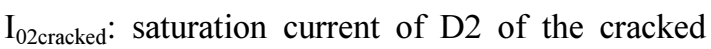
cell in A.

As PV panels generally expected to operate at MPP, the $\mathrm{I}_{\mathrm{MPP}}$ (current at maximum power point in $\mathrm{A}$ ) is lower than the $\mathrm{I}_{\mathrm{SC}}$, no power decrease is noted if the following equation is respected [7]:

$$
\frac{A_{\text {inactive }}}{A_{\text {total }}}<\frac{I_{S C}-I_{M P P}}{I_{S C}}
$$

However, when the isolated cell area increases (exceeding $8 \%$ ), we start noticing power losses. The cell becomes reverse biased and the current of the string flows through it. If its breakdown voltage is high, the current flows in the bypass diode if present [7]. It must be noted that having one or more cracked cells in a string lead approximately to the same power loss. The power loss depends from the cell having the maximum isolated area.

Table 2 is used to assign the fraction of inactive area of each cell according to the overview discussed in section V.

Table 2. Inactive area repartition.

\begin{tabular}{|c|c|c|c|c|c|}
\hline 0.4 & 0 & 0 & 0 & 0 & 0.4 \\
\hline 0 & 0.4 & 0.6 & 0.6 & 0.4 & 0 \\
\hline 0 & 0.4 & 0.6 & 0.6 & 0.4 & 0 \\
\hline 0.4 & 0 & 0 & 0 & 0 & 0.4 \\
\hline
\end{tabular}

\section{SIMULATION}

\section{A. Simulation of a TCO based Panel}

Panels equipped with a TCO are not crystalline based panels, they are CdTe or dye-sensitized panels. They undergo PID, UVD, and MID degradation.

The PV panel Model is built under Matlab/Simulink/Simscape. It consists of two strings of 12 cells each. They are configured according to Fig 2 . The series resistor $R_{S}$ of the equivalent circuit is varied according to equation 4 and to table 1 . The shunt resistor $R_{\text {sh }}$ and the series resistor $R_{s}$ vary also because of PID and UVD degradations [8]. The temperature is made variable during the day and during the year. The relative humidity is $50 \%$, the panel operates at $80 \mathrm{~V}$ to ground, and the irradiance is $1000 \mathrm{~W} / \mathrm{m}^{2}$. The power output at STC is measured. The Normalized efficiency is calculated for a period of 10 years following the equation:

$$
\text { NormalizedEfficiency }(t)=\frac{P_{S T C}(t)}{P_{S T C}(0)}
$$

In Fig 5, we see the simulation result of the TCO based panel. The normalized efficiency is represented for three different temperatures; $55^{\circ} \mathrm{C}$ in blue, $45^{\circ} \mathrm{C}$ in red, and $35^{\circ} \mathrm{C}$ in magenta. It is clear that high temperature increases the degradation of PV panels. First we have a high degradation caused by PID until the leakage current saturates [8]. The other degradations remains.

\section{B. Simulation of a grid based Panel}

Panels equipped with a metallic grid are generally crystalline based. They undergo PID, LID, UVD degradations and may be subject to cracks.

The PV panel Model is built under Matlab/Simulink/Simscape. It consists of two strings of 12 cells each. They are configured according to Fig 2. The short circuit current $\mathrm{I}_{\mathrm{sc}}$ and the diodes saturation currents $\mathrm{I}_{01}$ and $\mathrm{I}_{02}$

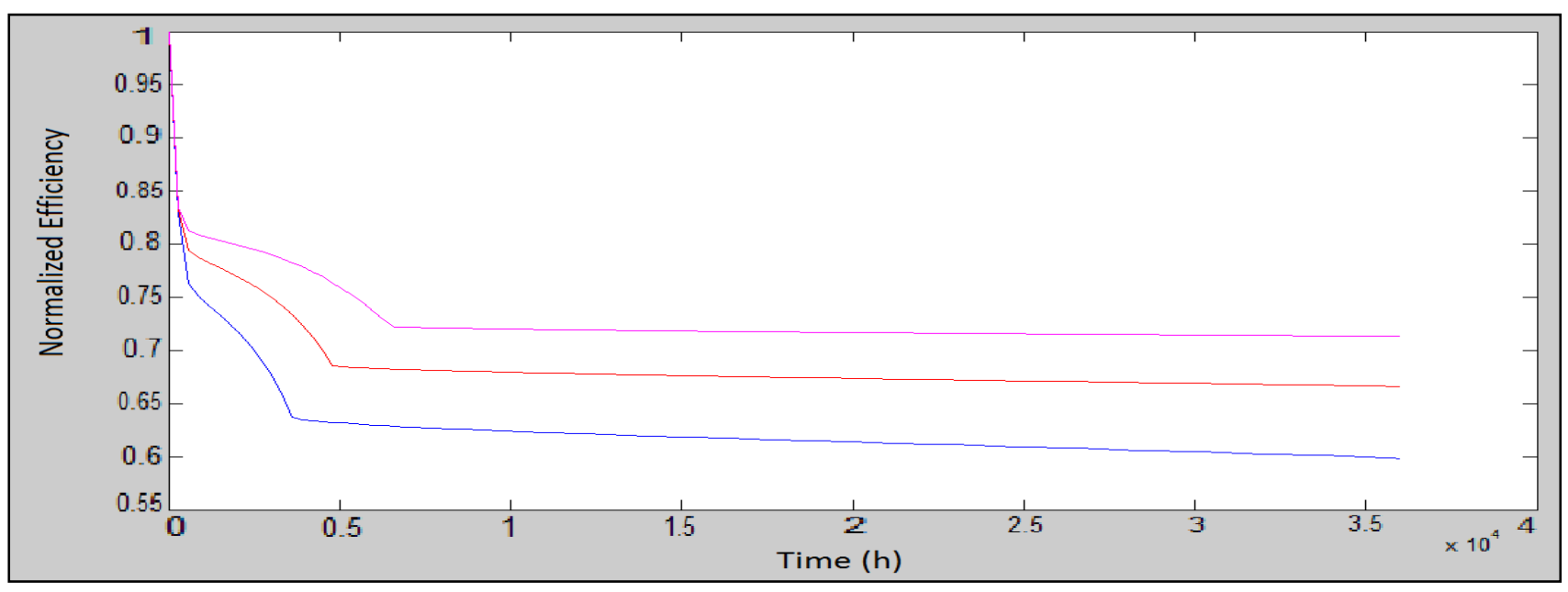

Figure 5. Normalized efficiency of a TCO based panel for 10 years. 


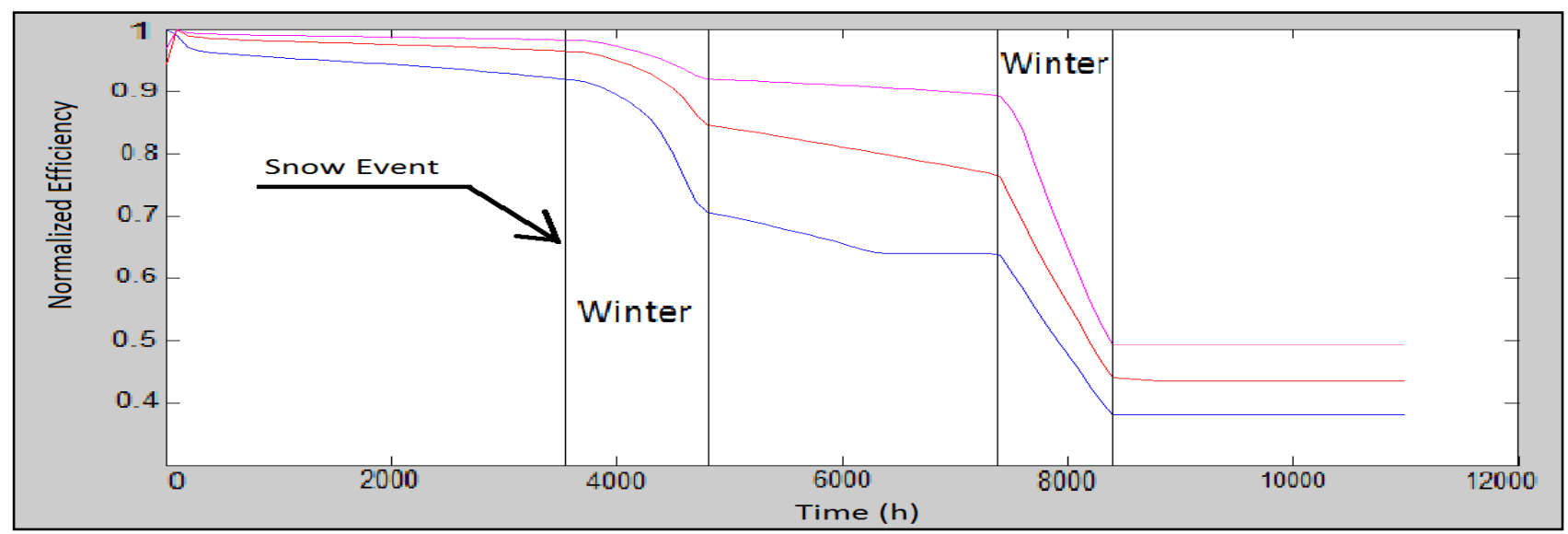

Figure 6 Normalised efficiency of a grid based PV panel for 3 years.

are varied according to equations 5, 6, and 7. The shunt resistor $R_{\text {sh }}$, the series resistor $R_{s}$, and the diodes saturation currents $I_{01}$ and $\mathrm{I}_{02}$ also vary because of PID, LID, and UVD degradations [8]. The relative humidity is $50 \%$, the panel operates at $80 \mathrm{~V}$ to ground, and the irradiance is $1000 \mathrm{~W} / \mathrm{m}^{2}$.

We consider one snow event that produces the cracks. Then we will need 200 nights (two winters) of freeze to reach the maximum degradation point. We will adopt a linear degradation during the 200 freeze nights.

The power output at STC is measured. The Normalized efficiency is calculated for a period of 3 years following equation 9.

In Fig 6, we see the simulation result for grid based PV panel. The normalized efficiency is represented for three different day temperatures; $15^{\circ} \mathrm{C}$ in blue, $25^{\circ} \mathrm{C}$ in red, and $35^{\circ} \mathrm{C}$ in magenta. It is clear that high temperature increases the degradation of PV panels. The snow cracking event is programmed to happen at the beginning of the second operating year ( $t=3650$ hours). The effect of cracks increases during winter.

\section{CONCLUSION}

In this paper we presented two degradation modes of PV panels. The MID that increases the cell TCO resistance was described and simulated. Then the cells cracks were described and simulated for crystalline silicon panels. The degradations modes found in literature were analyzed and studied to build a mathematical model of a PV panel that degrades with time. The two models take also into consideration the PID, the LID and the UVD. The simulation results show the efficiency decrease of PV panels as a function of environmental situation.

To mitigate MID degradation process we must build good sealed panels to avoid ingress of moisture. Another way is to decrease the temperature of the panel.

To mitigate the cracks effects on PV panels we must first try avoiding cracks formation or prevent freeze cycles. We may also design a metallic grid that is not affected by the cell cracks.
Our objective is to increase PV panel's lifetime to 40 years. Our future work will focus on exploring all degradation modes. Then we will try to apply ICT (Information and Communication Technologies) to alleviate the effect of environment on degradation of PV panels.

\section{REFERENCES}

[1] Luque Antonio and Hegedus Steven, 2011. Handbook of Photovoltaic Science and Engineering, England: Wiley.

[2] Melissa A. Yaklin, Duane A. Schneider, Kirsten Norman, Jennifer E. Granata, and Chad L. Staiger. "Impacts of Humidity and Temperature on the Performance of Transparent Conducting Zinc Oxide", 35th IEEE Photovoltaic Specialists Conference (PVSC),_2010, pp. 2493-2496.

[3] Michael D. Kempe. "Control of moisture ingress into photovoltaic modules", 31th IEEE Photovoltaic Specialists Conference (PVSC), 2005, pp. 503-506.

[4] Jane Kapur, Jennifer L. Norwood, and Colin D. Cwalina. "Determination of Moisture Ingress Rate through Photovoltaic Encapsulants", 39th IEEE Photovoltaic Specialists Conference (PVSC), 2013, pp. 3020-3023.

[5] Sarah Kajari-Schröder, Iris Kunze, Ulrich Eitner and Marc Köntges. "Spatial and directional distribution of cracks in silicon PV modules after uniform mechanical loads", 37th IEEE Photovoltaic Specialists Conference (PVSC),_2011, pp. 833-837.

[6] S. Kajari-Schröder, I. Kunze, M. Köntges. "Criticality of cracks in PV modules", SiliconPV, 2012, pp. 658-663.

[7] M. Köntges, I.Kunze, S.Kajari-Schröder, X. Breitenmoser, B. Bjørneklett. 2011. "The risk of power loss in crystalline silicon based photovoltaic modules due to micro-cracks", Solar Energy Materials \& Solar Cells 95: 1131-1137.

[8] Bechara Nehme, Nacer K. M'Sirdi, Tilda Akiki, Aziz Naamane. "Contribution to the modeling of ageing effects in PV cells and modules", to be published in SEB-2014.

[9] P-O. Westin, P. Neretnieks, and M. Edoff. "Damp heat degradation of CIGS-based PV modules", 21st European Photovoltaic Solar Energy Conference, 2006, pp. 2470-2473.

[10] Marco Paggi, Mauro Corrado, Maria Alejandra Rodriguez. 2013. "A multi-physics and multi-scale numerical approach to microcracking and power-loss in photovoltaic modules", Composite Structures 95: 630638 . 